\title{
Examination of technology acceptance and TPACK competencies of mathematics teachers who are involved in distance education practices during the pandemic process
}

\author{
Ozan Deniz KIYICI ${ }^{\text {* }}$ (D), Filiz Tuba DİKKARTIN ÖVEZ b (i) \\ ${ }^{a}$ Ministry of National Education, Turkey \\ ${ }^{\mathrm{b}}$ Balikesir University, Turkey
}

Suggested citation: Kıyıc1, O. D. \& Dikkartın Övez, F. T. (2021). Examination of technology acceptance and TPACK competencies of mathematics teachers who are involved in distance education practices during the pandemic process. Journal of Educational Technology \& Online Learning, 4(4), 805-821.

\begin{tabular}{ll}
\hline Article Info & Abstract \\
\cline { 2 - 3 } $\begin{array}{l}\text { Keywords: } \\
\text { Technology acceptance } \\
\text { Technological pedagogical } \\
\text { content knowledge }\end{array}$ & $\begin{array}{l}\text { Distance education has become an important opportunity for teachers who do not use } \\
\text { technology or use it little in learning environments to use ICT tools such as graphic } \\
\text { tablets, interactive content and dynamic geometry software by requiring them to perform } \\
\text { their courses with technological tools. In this regard, the present study aims to examine } \\
\text { the technology acceptance and TPACK competencies of mathematics teachers in the } \\
\text { distance education process that has been put into practice due to the impact of the } \\
\text { pandemic on a global scale. In the study, exploratory correlational and causal- } \\
\text { comparative research models were used. The sample of the study consists of } 223 \text { teachers } \\
\text { selected from the mathematics teachers who perform mathematics education practices } \\
\text { through distance education with criterion sampling, one of the purposive sampling } \\
\text { methods. The personal information form, Technology Acceptance Scale for Teachers } \\
\text { and TPACK Scale were used as data collection tools. In order to examine whether the } \\
\text { technology acceptance scores and TPACK levels differed according to various variables, } \\
\text { the independent t-test and the analysis of variance (one-way ANOVA) were applied. }\end{array}$ \\
Research/Review Article &
\end{tabular}

\section{Introduction}

Along with the pandemic called Covid-19, the education and instruction system has been affected, as have many sectors around the world. As a result of the search for measures to minimize the negative effects of the pandemic, emergency distance education has been put into practice in many countries and education activities have been continued. Distance education, which also existed before, has become an essential part of education at all levels after the pandemic. Thus, students and teachers who have not had any distance education experience before have found themselves as parts of distance education. Although some universities in Turkey have experience in distance education, distance education has been used for the first time in schools under the Ministry of National Education (MNE).

Distance learning is defined as the development of a student's knowledge or behavior during times when a student and a teacher cannot share the same environment due to situations limited by time or distance (King, Young, Driver-Richmond and Schrader, 2001). In other words, distance education is a system in which

\footnotetext{
* Corresponding author. Ministry of National Education, Turkey.

e-mail address: ozankiyici@gmail.com

This study was partly presented as a proceeding at the 1st International Conference on Educational Technology and Online Learning Conference held between 22-24 September 2021.
} 
education is maintained with the help of technology without the need for students and teachers to be together in the same environment (İşman, 2011). The historical development of distance education, which exists in the literature but is becoming even more significant today, began with printed materials based on correspondence, the so-called first-generation correspondence model. It can be listed as follows; the second-generation multimedia model, with the addition of technologies such as audio and video to printed materials, the third-generation telelearning model with the addition of telecommunications technologies to enable simultaneous training opportunities, the fourth-generation-flexible learning model that emerged with the development of internet-based access technologies and the fifth-generation intelligent flexible learning model including campus learning systems based on increased use of the internet (Taylor, 2001). It has become a necessity of our era to take advantage of the opportunities provided by technology in distance education, of which philosophy of emergence is the freedom of time and space to students and teachers (Bağrıçık Yılmaz and Karataş, 2020).

Distance education can be performed in two different ways, synchronous and asynchronous. Synchronous distance education is defined as a type of distance education that can be performed in the form of teleconference or online chat, where there are simultaneous interactions between the student and the teacher, whereas asynchronous distance education is defined as a type of distance education in which there is no simultaneous interaction between the student and the teacher, the video of the course content is watched by the student, and web or server-based education is provided (King et al., 2001; Yorganc1, 2014). In the era that we are going through, the students are directed to the content on the Educational Informatics Network (EBA), the new content of the courses is provided to the students asynchronously via television channels prepared for distance learning. Currently, courses are performed synchronously via some web conferencing tools.

King et al. (2001) states that traditional face-to-face education and distance education have different opportunities, and in some cases there are times when distance education may be even superior. By combining distance education and technology, it is possible to create environments where student-teacher interaction is maintained as in face-to-face training, educational content is visually enriched and interactive tools in which the student can participate effectively in the process are used (Akyürek, 2020; Odabaş, 2003).

The complete digitization of the educational process makes the digital literacy levels of today's students and teachers living in the information era an essential tool. Although the students who are familiar with technology and actively use technology, identified as digital natives, master the use of technology, teacher guidance is required on the effective use of information and communication technologies (Karabulut, 2015; MNE, 2020). In this case, it becomes significant for teachers to master the ICT tools they use in the distance learning process, to correctly determine which ICT tool to use in which conditions, to ensure that students interact by providing a variety of ICT tools, and to have competence, perception, and attitudes towards the ICT tools used (Ursavaş, Şahin, and McIlroy, 2014).

Mathematics is regarded as a discipline that has little effect when using plain language by its nature and for which the success of students increases in learning environments where different teaching methods and ICT tools are used (Aydos, 2015; Baz, 2016; Öz, 2015; Zaranis, 2016). Bringing ICT tools to the classrooms by teachers may be limited to the use of smart boards or computers only due to situations such as the lack of sufficient infrastructure, classes without internet access, and the fact that not every student has a tablet or computer that they can use during the lesson. This may lead to the fact that not every student can be effectively involved in the process. In addition, it is known that some teachers do not deviate from traditional methods and that they carry out classroom activities based solely on the exam system. With the transition of the education process to distance education, although it is due to a sudden obligation, students need a phone, tablet, or computer in order to attend the lesson. That each student participating in the course will have a technological device, provides a great opportunity to integrate ICT tools into mathematics courses during the distance learning process. With the effective design of the learning environment, all students participating in the course can be effectively involved in ICT integrated courses. While integrating 
ICT into the learning-teaching process, various models have been developed in which the stages of the integration process are determined, the integration process or the elements of integration are explained (Mazman and Usluel, 2011).

In the literature, we can see studies that compare distance education environments (Herand and Hatipoğlu, 2014; İzmirli and Akyüz, 2017), examine distance education from the perspective of academicians (Durak and Çankaya, 2020), examine the views of teacher candidates from different branches on distance education (Karakuş, Ucuzsatar, Karacaoğlu, Esendemir, and Bayraktar, 2020; Karatepe, Küçükgençay and Peker, 2020), and examine the opinions of teachers on distance education practices during the Covid-19 pandemic period (Bakioğlu and Çevik, 2020; Başaran, Doğan, Karaoğlu, and Şahin, 2020; Bayburtlu, 2020; Demir and Özdaş, 2020; Hebebci, Bertiz, and Alan, 2020; Kocayiğit and Uşun, 2020; Kurnaz, Kaynar, Barış1k and Doğrukök, 2020). Similarly, in the research carried on the attitudes of teachers towards the use of technology while teaching mathematics during the covid-19 pandemic period, it has been determined that teachers have a positive attitude towards technology in terms of behavioral commitment and trust, and a highly positive attitude in terms of affective participation (Marpa, 2020). In the study carried out on the awareness of teachers of the Covid-19 pandemic and their experiences with the distance education process that emerged in this process, institutional readiness and perceptions of difficulties, it was found that the awareness of teachers of the pandemic was high, and that there was a strong relationship between readiness for distance education and the duration of teaching experience and specialization in distance education (Alea, Fabrea, Roldan and Farooqi, 2020). Also, another study concluded that mathematics teachers use technology regularly and participate in online activities to improve themselves (Perienen, 2020).

With the development of ICT tools, interest in the use of technology in educational environment has increased. It is noted that the motivation, knowledge and skills of teachers about information technologies have a great impact on the integration of ICT tools in learning environments, and it is necessary to better understand the use and acceptance of technology by teachers (Ursavaş et al., 2014). Many researchers have studied on revealing how people would react to the changes they experienced and their resistance to using new technologies with the Technology Acceptance Model (Davis, 1989). Similarly, Rogers' (1995) Theory, Diffusion of Innovations, offered a five-step model for the adoption and acceptance of new technologies. Individuals who know innovation evaluates the characteristics related to innovation with variables such as their own characteristics, socio-economic differences. As a result of the evaluation, the individuals begin to use innovation, reassess, and explain their own decision on the acceptance of innovation. Thus, steps to provide explanations have been taken for the adoption or rejection of individuals by adapting to the constantly evolving technology (Niess, Ronau, Shafer, Driskell, Harper, Johnston, Browning, Özgün-Koca, Kersaint, 2009).

In addition, it is seen significant that mathematics teachers have the necessary knowledge to integrate teaching and technology in the process of distance mathematics education (Dikkartın Övez and Akyüz, 2013). With the global pandemic, the transition to distance education in the education system has made it mandatory for teachers who do not use technology or use it little in learning environments to conduct their courses with technological tools. Due to the nature of the mathematics course, the use of graphic tablets to perform actions such as writing and drawing, interactive videos, interactive content developed with web 2.0 tools, and ICT tools such as dynamic geometry software have created an important opportunity to ensure active participation of students in the course and to enrich the learning environment. In this regard, the objective of the study has been set as to examine the technology acceptance and TPACK competencies of mathematics teachers in the distance education process that has been put into practice due to the impact of the Covid-19 pandemic on a global scale. The problem situations for this objective are listed as follows:

- At what levels are the technology acceptance and TPACK competency of mathematics teachers? 
- Is there a significant difference between the technology acceptance and TPACK competencies of mathematics teachers according to various variables (gender, age, professional seniority, department graduated from, in-service training status, graphic tablet usage, technology usage level)?

- Is there a significant relationship between the technology acceptance and TPACK competency levels of mathematics teachers?

\section{Methodology}

\subsection{Research Model/Design}

In this research, the survey model was adopted among the quantitative research methods. In addition, the causal-comparison approach was also used among the relational screening models as the research aims to evaluate the technology acceptances and TPACK proficiency of mathematics teachers in terms of gender, age, year of study, graduated department, in-service retrieval status, graphic tablet use, technology usage level. The correlational approach was adopted among the relational screening models to examine the relationship between technology acceptance of mathematics teachers and the TPACK proficiency levels. In addition, the relational models are used in examining whether there is any relationship between two or more variables and the degree of that relationship; And in obtaining clues about cause and effect, and for better understanding of the facts examined (Büyüköztürk, Akgün, Demirel, Karadeniz \& Çakmak, 2016; Karasar, 2015).

\subsection{Data Collecting Tools.}

A three-part questionnaire was used to collect the data of the study. The first part contains a personal information form created by the researchers to determine the demographic status (gender, age, professional seniority, type of school, department graduated from, type of graduation, etc.) of the mathematics teachers participating in the study. In the second part, the Technology Acceptance Scale for Teachers: T-TAS developed by Ursavaş et al. (2014) was used to determine the technology acceptance levels of mathematics teachers. In the third part, the Technological Pedagogical Content Knowledge Scale, which was adapted into Turkish by Dikkartın Övez and Akyüz (2013), and which measures TPACK levels only for the mathematics course, of which reliability and validity were tested, was used to determine the TPACK competencies of mathematics teachers.

T-TAS is a five-point likert type scale consisting of a total of 37 items developed by Ursavaş et al. (2014). The scale contains five options in the form of strongly disagree (1), disagree (2), uncertain (3), agree (4), strongly agree (5). While evaluating the T-TAS scores, which are found by dividing the sum of the answers given by the participants to the scale questions by the number of questions in the questionnaire, the scale 1.00-1.80: strongly disagree, 1.81-2.60 disagree, 2.61-3.40 uncertain, 3.41-4.20 agree, 4.21-5.00 strongly agree will be used. In addition, when the level of technology use is considered with the scale, mathematics teachers are asked what level they see themselves more. These levels are listed as follows (Ursavaş, 2014): Introduction: Inexperienced but willing in technology use. At this stage, an educator either uses the technology very little or does not use it at all.

Adoption: Using technology to support traditional education. At this stage, the technology use of an educator usually takes place as an activity isolated from the learning-teaching process.

Adapting: Integrating technology into learning activities. At this stage, educators began to realise the potential of technology in improving their own and their students' productivity.

Exploring: Developing new teaching approaches and strategies that consider the advantages of technology. At this stage, an educator feels very comfortable with the technology use and fully integrated the technology into the school's curriculum.

Advancing: Advancing of technology tools. At this stage, educators begin to think about how to handle the routine activities they were doing differently and explore new ways with the technology. 
As the scale scores are between 1.00 and 5.00, it was accepted that the participation levels of the students in the scale items are higher as the scores approach 5.00 and lower as they approach 1.00. The reliability coefficients of the scale were examined separately according to the factors included in the scale and the highest is calculated as .909 , and the lowest is calculated as .798. The validity of the scale was maintained through the stages of convergent and discriminant validity.

The TPACK scale, which is used to determine the TPACK levels of mathematics teachers, is a five-point likert type scale consisting of 27 items. The scale contains five options in the form of strongly disagree (1), disagree (2), uncertain (3), agree (4) and strongly agree (5). While evaluating the TPACK scores, which are found by dividing the sum of the answers given by the participants to the scale questions by the number of questions in the questionnaire, the scale 1.00-1.80: strongly disagree, 1.81-2.60 disagree, 2.61-3.40 uncertain, 3.41-4.20 agree, 4.21-5.00 strongly agree was used. As the scale scores are between 1.00 and 5.00 , it will be accepted that the participation levels of the students in the scale items are higher as the scores approach 5.00 and lower as they approach 1.00. The TPACK scale consists of four factors: Knowledge of Technology (KT), Knowledge of Mathematics (KM), Knowledge of Mathematics Teaching (KMT) and Knowledge of Technology in Mathematics Teaching (KTMT). The reliability coefficients of the scale were examined separately according to the factors included in the scale; the highest is calculated as .86, and the lowest is calculated as .82 .

\subsection{Sampling or Study Group}

Due to the pandemic, hybrid education and distance education have been used by the Ministry of National Education in addition to face-to-face education. In accordance with the objective of the study, it is necessary to carry out the research with teachers who perform mathematics education through distance education. It is a well-known fact that in mathematics courses abstract concepts are especially intense and that different representations such as graphics, context, pattern table equations should be used rather than verbal expressions. In this process, distance education and mathematics teaching are important to ensure greater student participation in transactional applications compared to other disciplines, to use technological tools effectively and to integrate technology into mathematics courses. As a result, revealing the TPACK characteristics and perspectives of mathematics teachers on technology is necessary. Therefore, the study was carried out with mathematics teachers.

In order to determine the mathematics teachers who will participate in the study in this regard, criterion sampling was used among the purposeful sampling methods. The reason for using criterion sampling is that we study the situations that meet the predetermined criterion. The criterion here may be a criterion used by the researcher or a pre-prepared list of criteria (Büyüköztürk et al., 2016; Yıldırım and Şimşek, 2003). Thus, 223 mathematics teachers who were selected considering the participation in distance education applications with the criterion sampling method constitute the study group. Descriptive statistics related to the demographic information of the teachers participating in the study are presented in Table 1.

Table 1.

Demographic Information of the Teachers Participating in the Study

\begin{tabular}{|c|c|c|c|c|c|c|c|c|c|c|}
\hline \multirow[b]{2}{*}{$\begin{array}{l}\text { Teacher } \\
\text { Qualities }\end{array}$} & \multicolumn{2}{|c|}{ Gender } & \multicolumn{2}{|c|}{$\begin{array}{c}\text { Type of School } \\
\text { Worked in }\end{array}$} & \multicolumn{3}{|c|}{ Department Graduated from } & \multicolumn{3}{|c|}{ Type of Graduation } \\
\hline & 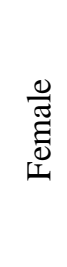 & $\frac{0}{\tilde{J}}$ & 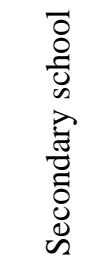 & $\begin{array}{l}\overline{8} \\
0 \\
0 \\
0 \\
0 \\
\text { b0 } \\
\text { in }\end{array}$ & 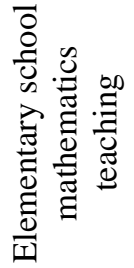 & 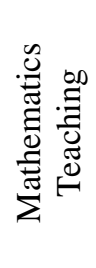 & 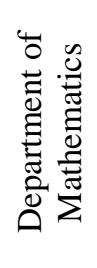 & 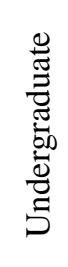 & 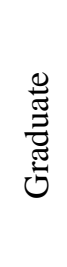 & $\stackrel{\theta}{A}$ \\
\hline Frequency & 136 & 87 & 141 & 82 & 122 & 38 & 63 & 170 & 50 & 3 \\
\hline
\end{tabular}




\begin{tabular}{lllllllllll} 
Percentage & 61 & 39 & 63.2 & 36.8 & 54.7 & 17 & 28.3 & 76.2 & 22.4 & 1.4 \\
\hline
\end{tabular}

According to Table 1, it can be seen that $136(61 \%)$ of the mathematics teachers participating in the study were female, 87 (39\%) were male; $141(63.2 \%)$ of them worked in secondary school and $82(36.8 \%)$ worked in high school; 122 of them $(54.7 \%)$ graduated from elementary school mathematics teaching, $38(17 \%)$ from mathematics teaching, $63(28.3 \%)$ from mathematics department; 170 (76.2\%) of them completed an undergraduate degree, $50(22.4 \%)$ of them completed a graduate degree and $3(1.4 \%)$ of them completed PhD degree.

Table 2 shows the age and professional seniority of the teachers participating in the study.

\section{Table 2.}

Distribution of the mathematics teachers' age and professional seniority of employment

\begin{tabular}{|c|c|c|c|c|c|}
\hline & & \multicolumn{2}{|c|}{ Gender } & \multirow{2}{*}{\multicolumn{2}{|c|}{ Total }} \\
\hline & & Female & Male & & \\
\hline & & $f$ & $f$ & $f$ & $\%$ \\
\hline \multirow{5}{*}{ Age } & Age 27 and younger & 17 & 1 & 18 & 8.1 \\
\hline & Between ages $28-35$ & 71 & 41 & 112 & 50.2 \\
\hline & Between ages $36-43$ & 27 & 25 & 52 & 23.3 \\
\hline & Between ages $44-51$ & 19 & 9 & 28 & 12.6 \\
\hline & Age 52 and older & 2 & 11 & 13 & 5.8 \\
\hline \multirow{5}{*}{ Professional Seniority } & $1-5$ years & 25 & 4 & 29 & 13.0 \\
\hline & $6-10$ years & 59 & 31 & 90 & 40.4 \\
\hline & $11-15$ years & 14 & 14 & 28 & 12.6 \\
\hline & $16-20$ years & 16 & 12 & 28 & 12.6 \\
\hline & 20 years and more & 22 & 26 & 48 & 21.5 \\
\hline
\end{tabular}

According to Table 2, $18(8.1 \%)$ of the mathematics teachers participating in the research were 27 years old and younger, $112(50.2 \%)$ of them were between 28 and 35 years old, $52(23.3 \%)$ of them were between 36 and 43 years old, $28(12.6 \%)$ of them were between 44 and 51 years old, $13(5.8 \%)$ were 52 years old and older; $29(13.0 \%)$ of them had between 1 and 5 years $90(40.4 \%)$ of them had between 6 and 10 professional seniority, $28(12.6 \%)$ of them had 11 and 15 years, $28(12.6 \%)$ of them had16 and 20 years, $48(21.5 \%)$ of them had 20 or more years.

Table 3 shows the demographic information of the mathematics teachers participating in the study about the use of technology.

Table 3.

Demographic Information of the Teachers Participating in the Study about the Use of Technology

\begin{tabular}{|c|c|c|c|}
\hline Teacher Qualities & Option & Frequency & Percentage \\
\hline \multirow{5}{*}{ Technology Use Level } & Beginner & 13 & 5.8 \\
\hline & Acceptance & 31 & 13.9 \\
\hline & Adaptation & 61 & 27.4 \\
\hline & Exploring & 72 & 32.3 \\
\hline & Advancing & 46 & 20.6 \\
\hline \multirow{2}{*}{ ICT In-Service Training Status } & Yes & 120 & 53.8 \\
\hline & No & 103 & 46.2 \\
\hline Use of Graphic Tablets in the Process of & I do & 123 & 55.2 \\
\hline Distance Learning & I do not & 100 & 44.8 \\
\hline
\end{tabular}


According to Table 3, $120(53,8 \%)$ of the teachers stated that they received in-service training on ICT tools, $103(46,2 \%)$ stated that they did not; $123(55,2 \%)$ of them stated they used a graphic tablet in distance education, $100(44,8 \%)$ stated they did not; and $13(5,8 \%)$ of them considered themselves in the elementary level, $61(27,4 \%)$ of them as accepting, $72(32,3 \%)$ of them as exploring and $46(20,6 \%)$ of them as advancing of areas levels in terms of their levels of use of technology.

\subsection{Data Analysis}

While determining whether the data are suitable for normal distribution in order to determine the appropriate statistical techniques for the analysis of the data obtained from the scales used in the research. the Kolmogorov-Smirnov test was applied (Büyüköztürk, 2015). As a result of the Kolmogorov-Smirnov test, it was determined that the $\mathrm{p}$ value of the Technology Acceptance Scale for Teachers and the Technological Pedagogical Content Knowledge Scale was less than .05 (K-S T-TAs: 0.060, K-S TPACK: 0.102 However, since the skewness and kurtosis coefficients of the scales are between +1 and -1 , it is accepted that the data obtained show a normal distribution (Büyüköztürk, 2015). In addition, it is noted that the data with skewness and kurtosis values between -1.5 and +1.5 show normal distribution (Tabachnick and Fidell, 2013). In the analysis, the skewness value of T-TAS is -0.224 and the kurtosis value is -0.147 ; It was observed that the skewness value of the TPACK scale was -0.277 and the kurtosis value was -0.741 .

According to this result, it was determined that the data obtained from the scales did not deviate much from the normal distribution. Based on the conclusion that the data showed a normal distribution, independent samples t-test was conducted to examine whether mathematics teachers' technology acceptance scores and technological pedagogical content knowledge levels differ according to the variables of gender, graphic tablet use and in-service training on ICT, while analysis of variance (one-way ANOVA) was conducted to determine whether it differs according to age, professional seniority, department graduated and level of technology use. Tukey HSD is used in case of equality of variances during ANOVA test. The correlation coefficient was calculated to determine whether there is a significant relationship between the technology acceptance levels of mathematics teachers and their TPACK competencies (Büyüköztürk, 2015).

\section{Findings}

Descriptive statistics of the technology acceptance and technological pedagogical content knowledge levels of the mathematics teachers participating in the study are shown in Table 4.

\section{Table 4.}

Descriptive statistics of the scores of the T-TAS and TPACK scales

\begin{tabular}{cccccc}
\hline Scales & $\mathrm{N}$ & Minimum & Maximum & $\bar{X}$ & SD \\
\hline T-TAS & 223 & 2.54 & 5.00 & 3.90 & .4796 \\
TPACK & 223 & 2.78 & 5.00 & 4.20 & .5299 \\
\hline
\end{tabular}

According to Table 4, mean of the technology acceptance scores of mathematics teachers is $\bar{X}=3.90$, and the technological pedagogical content knowledge scores is $\bar{X}=4.20$. The obtained mean scores correspond to the "agree" option in the scaling. In this case, it can be said that mathematics teachers have high levels of technology acceptance and technological pedagogical content knowledge.

In order to compare the technology acceptance levels and TPACK competencies of mathematics teachers according to their gender, the independent sample t-test was analyzed. The results obtained from the analysis are shown in Table 5. 


\section{Table 5.}

Technology acceptance and TPACK levels of teachers by gender

\begin{tabular}{ccccccccc}
\hline Scales & Gender & $\mathrm{N}$ & $\bar{X}$ & $\mathrm{SD}$ & $\mathrm{df}$ & $\mathrm{t}$ & $\mathrm{p}^{*}$ \\
\hline \multirow{2}{*}{ T-TAS } & Female & 136 & 3.84 & 0.4723 & 221 & -2.329 & $.021^{*}$ \\
& Male & 87 & 4.00 & 0.4790 & & \\
& Female & 136 & 4.07 & 0.5110 & 221 & -4.606 & \multirow{2}{*}{$.000^{*}$} \\
\hline \multirow{2}{*}{ TPACK } & Male & 87 & 4.40 & 0.5014 & & \\
& & &
\end{tabular}

$(* \mathrm{p}<.05)$

According to Table 5, the mean total T-TAS score of male teachers is higher than the mean T-TAS score of female teachers. When the data obtained from the t-test results conducted to determine the significance of this difference are examined, it is seen that there is a significant difference in the technology acceptance levels of mathematics teachers in terms of gender $\left(\mathrm{t}_{[221]}=-2.329, \mathrm{p}<.05\right)$. When looking at the average scores of the TPACK scale, it is seen that the mean scores of male teachers are higher than that of female teachers. When the data obtained from the t-test results conducted to determine the significance of this difference are examined, it is seen that there is a significant difference in the TPACK competencies of mathematics teachers in terms of gender $\left(\mathrm{t}_{[221]}=-4.606, \mathrm{p}<.05\right)$. According to these results, it can be said that the acceptance levels and technological pedagogical content knowledge competencies of male teachers' classroom technologies are higher than that of female teachers.

In order to compare the technology acceptance levels and TPACK competencies of mathematics teachers according to use of graphic tables in the distance education, the independent samples t-test was conducted. The results obtained from the analysis are shown in Table 6.

Table 6.

Technology acceptance and TPACK levels of teachers according to the use of graphic tablets in the distance learning process

\begin{tabular}{|c|c|c|c|c|c|c|c|}
\hline Scales & $\begin{array}{c}\text { Graphic Tablet } \\
\text { Use }\end{array}$ & $\mathrm{N}$ & $\bar{X}$ & SD & $\mathrm{df}$ & $\mathrm{t}$ & $\mathrm{p}^{*}$ \\
\hline \multirow{2}{*}{ T-TAS } & Yes & 123 & 3.95 & 0.4591 & \multirow{2}{*}{221} & \multirow{2}{*}{1.513} & \multirow{2}{*}{.132} \\
\hline & No & 100 & 3.85 & 0.5008 & & & \\
\hline \multirow{2}{*}{ TPACK } & Yes & 123 & 4.25 & 0.5289 & \multirow{2}{*}{221} & \multirow{2}{*}{1.714} & \multirow{2}{*}{.088} \\
\hline & No & 100 & 4.13 & 0.5260 & & & \\
\hline
\end{tabular}

$(* \mathrm{p}<.05)$

According to Table 6, the total T-TAS mean score of the mathematics teachers who use graphic tablets in the distance learning process is seen higher $(\bar{X}=3.95)$, compared to those who do not use graphic tablets in the process of distance learning $(\bar{X}=3.85)$. When the data obtained from the independent samples t-test results carried out to determine the significance of this difference are examined, it is seen that there is no significant difference in the technology acceptance levels of mathematics teachers who use graphic tablets in the distance education process compared to those who do not $\left(\mathrm{t}_{[221]}=1.513, \mathrm{p}>.05\right)$. When the mean scores of the TPACK scale are examined, it is seen that there is no significant difference between the use of graphic tablets by mathematics teachers in the distance education process and their technological pedagogical content knowledge competencies $\left(\mathrm{t}_{[221]}=1.714, \mathrm{p}>.05\right)$. According to these results, it can be said that the use of graphic tablets in the distance learning process does not have a relationship with the technology acceptance and TPACK competencies of mathematics teachers. 
In order to compare the status of teachers receiving in-service instruction on the use of ICT with their technology acceptance levels and TPACK competencies, the independent sample t-test was conducted. The results obtained from the analysis are shown in Table 7.

Table 7.

Technology acceptance and TPACK levels of teachers according to their status of receiving in-service instruction on the use of ICT

\begin{tabular}{cccccccc}
\hline \multirow{2}{*}{ Scales } & $\begin{array}{l}\text { Status of receiving in-service } \\
\text { instruction on the use of ICT }\end{array}$ & $\mathrm{N}$ & $\bar{X}$ & $\mathrm{SD}$ & $\mathrm{df}$ & $\mathrm{t}$ & $\mathrm{p}^{*}$ \\
\hline \multirow{2}{*}{ T-TAS } & Yes & 120 & 3.95 & 0.4555 & \multirow{2}{*}{221} & \multirow{2}{*}{1.493} & .137 \\
\hline \multirow{2}{*}{ TPACK } & No & 103 & 3.85 & 0.5035 & & \\
& Yes & 120 & 4.19 & 0.5268 & \multirow{2}{*}{221} & \multirow{2}{*}{0.206} & .837 \\
\hline
\end{tabular}

$(* \mathrm{p}<.05)$

According to Table 7, the mean of the scores obtained from the T-TAS and TPACK scales of mathematics teachers who have received in-service instruction on the use of ICT and who have not are very close to each other. According to the results of the independent samples t-test conducted to examine the significance of the difference, it is seen that there is no significant difference between the mathematics teachers' status of receiving in-service instruction on ICT, their technology acceptance level and their technological pedagogical content knowledge levels. According to these results, it can be said that receiving in-service instruction on the use of ICT does not affect the technology acceptance and TPACK competencies.

ANOVA test was performed to determine whether the scores obtained by mathematics teachers from the T-TAS and TPACK scales were significantly different according to the age of mathematics teachers. Descriptive statistics related to the ages of the teachers are shown in Table 8, and the results obtained with the ANOVA test are shown in Table 9.

\section{Table 8.}

The distribution of the mean scores obtained from the T-TAS and TPACK scales according to age

\begin{tabular}{ccccc}
\hline & Age & $\mathrm{N}$ & $\bar{X}$ & SD \\
\hline \multirow{4}{*}{ T-TAS } & Age 27 and younger & 18 & 4.10 & .4965 \\
& Between ages 28-35 & 112 & 3.91 & .4980 \\
& Between ages 36-43 & 52 & 3.86 & .4139 \\
& Between ages 44-51 & 28 & 3.79 & .4472 \\
TPACK & Age 52 and older & 13 & 4.01 & .5692 \\
\hline & Age 27 and younger & 18 & 4.21 & .6087 \\
& Between ages 28-35 & 112 & 4.26 & .5422 \\
& Between ages 36-43 & 52 & 4.11 & .5221 \\
& Between ages 44-51 & 28 & 4.16 & .4654 \\
\hline
\end{tabular}

Table 9.

ANOVA results of T-TAS and TPACK scores according to age

\begin{tabular}{|c|c|c|c|c|c|c|}
\hline Scales & & $\begin{array}{c}\text { Sum of } \\
\text { Squares }\end{array}$ & df & Mean Square & $\mathrm{F}$ & $\mathrm{p}^{*}$ \\
\hline \multirow{3}{*}{ T-TAS } & Between Groups & 1.323 & 4 & 0.331 & \multirow{3}{*}{1.449} & \multirow{3}{*}{.219} \\
\hline & Within Groups & 49.752 & 218 & 0.228 & & \\
\hline & Total & 51.074 & 222 & & & \\
\hline \multirow{3}{*}{ TPACK } & Between Groups & 0.964 & 4 & 0.241 & \multirow{3}{*}{0.856} & \multirow{3}{*}{.491} \\
\hline & Within Groups & 61.378 & 218 & 0.282 & & \\
\hline & Total & 62.342 & 222 & & & \\
\hline
\end{tabular}

$(* \mathrm{p}<.05)$ 
According to Table 8, the scores obtained by the teachers from T-TAS and TPACK scales according to their age ranges are close to each other. According to Table 9, the acceptance of technology of mathematics teachers is not statistically significant according to age $\left[\mathrm{F}_{(4,218)}=1.449, \mathrm{p}>.05\right]$. It was determined that there was no statistically significant difference in the technological pedagogical content knowledge competencies of mathematics teachers according to age $\left[\mathrm{F}_{(4,218)}=0.856, \mathrm{p}>.05\right]$. According to these results, it can be said that there is no statistically significant between the levels of technology acceptance and technological pedagogical content knowledge levels of mathematics teachers.

ANOVA test was performed to determine whether the scores obtained by mathematics teachers from the T-TAS and TPACK scales were significantly different according to the professional seniortiy. Descriptive statistics for the professional seniortiy of teachers are shown in Table 10, and the results obtained with the ANOVA test are shown in Table 11.

\section{Table 10.}

The distribution of the mean scores obtained from the T-TAS and TPACK scales according to professional seniority

\begin{tabular}{ccccc}
\hline Scale & Professional Seniority & $\mathrm{N}$ & $\bar{X}$ & SD \\
\hline \multirow{3}{*}{ T-TAS } & $1-5$ years & 29 & 4.00 & .4745 \\
& $6-10$ years & 90 & 3.88 & .4813 \\
& $11-15$ years & 28 & 4.01 & .5342 \\
& $16-20$ years & 28 & 3.81 & .3804 \\
TPACK & 20 years and more & 48 & 3.88 & .4967 \\
& $1-5$ years & 29 & 4.26 & .5798 \\
& 6-10 years & 90 & 4.22 & .5341 \\
& $11-15$ years & 28 & 4.24 & .5813 \\
& $16-20$ years & 28 & 4.05 & .4568 \\
\hline
\end{tabular}

Table 11.

ANOVA results of T-TAS and TPACK scores according to professional seniority

\begin{tabular}{|c|c|c|c|c|c|c|}
\hline Scales & & $\begin{array}{c}\text { Sum of } \\
\text { Squares }\end{array}$ & $\mathrm{df}$ & Mean Square & $\mathrm{F}$ & $\mathrm{p}^{*}$ \\
\hline \multirow{3}{*}{ T-TAS } & Between Groups & 0.942 & 4 & 0.236 & \multirow{3}{*}{1.025} & \multirow{3}{*}{.395} \\
\hline & Within Groups & 50.132 & 218 & 0.230 & & \\
\hline & Total & 51.074 & 222 & & & \\
\hline \multirow{3}{*}{ TPACK } & Between Groups & 0.882 & 4 & 0.220 & \multirow{3}{*}{0.782} & \multirow{3}{*}{.538} \\
\hline & Within Groups & 61.640 & 218 & 0.282 & & \\
\hline & Total & 62.342 & 222 & & & \\
\hline
\end{tabular}

$(* \mathrm{p}<.05)$

According to Table 10, the scores obtained by the teachers from T-TAS and TPACK scales according to their professional seniority are close to each other. According to Table 11, it was concluded that there was no statistically significant difference between the mathematics teachers' technology acceptance level $\left[\mathrm{F}_{(4,218)}=1.025, \mathrm{p}>.05\right)$ and their TPACK level according to their professional seniority $\left[\mathrm{F}_{(4,218)}=0.782\right.$, $\mathrm{p}>.05)$.

ANOVA test was performed to determine whether the scores obtained by mathematics teachers from the T-TAS and TPACK scales were significantly different according to the department graduated. Descriptive statistics of the departments that the teachers graduated from are shown in Table 12, and the results obtained with the ANOVA test are shown in Table 13. 
Table 12.

Distribution of T-TAS and TPACK scores according to the department that the teachers graduated from

\begin{tabular}{ccccc}
\hline Scale & Departments & $\mathrm{N}$ & $\bar{X}$ & $\mathrm{SD}$ \\
\hline \multirow{2}{*}{ T-TAS } & Elementary school mathematics teaching & 122 & 3.92 & .4892 \\
& Mathematics teaching & 38 & 3.80 & .4528 \\
\hline \multirow{2}{*}{ TPACK } & Department of mathematics & 63 & 3.93 & .4755 \\
& Elementary school mathematics teaching & 122 & 4.18 & .5192 \\
& Mathematics teaching & 38 & 4.05 & .5423 \\
\hline
\end{tabular}

Table 13.

ANOVA results of T-TAS and TPACK scores according to the department that the teachers graduated from

\begin{tabular}{|c|c|c|c|c|c|c|c|}
\hline Scales & & $\begin{array}{l}\text { Sum of } \\
\text { Squares }\end{array}$ & df & Mean Square & $\mathrm{F}$ & $\mathrm{p}^{*}$ & $\begin{array}{l}\text { Significant } \\
\text { Difference }\end{array}$ \\
\hline \multirow{3}{*}{ T-TAS } & Between Groups & 0.502 & 2 & 0.251 & \multirow{3}{*}{1.092} & \multirow{3}{*}{.337} & \\
\hline & Within Groups & 50.572 & 220 & 0.230 & & & \\
\hline & Total & 51.074 & 222 & & & & \\
\hline \multirow[b]{3}{*}{ TPACK } & Between Groups & 1.738 & 2 & 0.869 & \multirow[b]{3}{*}{3.155} & \multirow[b]{3}{*}{.045} & Department of \\
\hline & Within Groups & 60.604 & 220 & 0.275 & & & Mathematics - \\
\hline & Total & 62.342 & 222 & & & & $\begin{array}{c}\text { Department of } \\
\text { mathematics } \\
\text { teaching }\end{array}$ \\
\hline
\end{tabular}

$(* \mathrm{p}<.05)$

According to Table 12, the scores obtained by the teachers from the T-TAS scale are close to each other according to the departments they graduated from; in the TPACK scale, however, it is seen that the scores obtained by the teachers who graduated from the mathematics department $(\bar{X}=4.32)$ are higher than the mean scores $(\bar{X}=4.05)$ obtained by the teachers who graduated from the mathematics teaching department.

According to Table 13, the technology acceptance level of mathematics teachers $\left[\mathrm{F}_{(2,220)}=1.092, \mathrm{p}>.05\right]$ does not show a significant difference according to the department they graduated from. However, it was found that the TPACK levels show a significant difference compared to the department graduated $\left[\mathrm{F}_{(2,220)}\right.$ $=3.328, \mathrm{p}<.05]$. Tukey HSD test, among the post hoc tests, was used to determine which groups this difference between TPACK levels was between. According to the results of this test, it was determined that the levels of technological pedagogical content knowledge were more positive for teachers who graduated from the mathematics department than for teachers who graduated from mathematics teaching $(\mathrm{p}<.05)$.

ANOVA test was performed to determine whether the scores obtained by mathematics teachers from the T-TAS and TPACK scales were significantly different according to the use of technology levels of mathematics teachers. Descriptive statistics of teachers' use of technology levels are shown in Table 14, and the results obtained with the ANOVA test are shown in Table 15. 
Table 14.

Descriptive statistics of teachers' use of technology levels according to the T-TAS and TPACK scores

\begin{tabular}{ccccc}
\hline Scale & Age & $\mathrm{N}$ & $\bar{X}$ & SD \\
\hline & Beginner & 13 & 3.79 & .6213 \\
T-TAS & Acceptance & 31 & 3.78 & .5507 \\
& Adaptation & 61 & 3.85 & .5217 \\
& Exploring & 72 & 4.02 & .4057 \\
TPACK & Advancing & 46 & 3.90 & .4091 \\
& Beginner & 13 & 3.84 & .6659 \\
& Acceptance & 31 & 4.07 & .4901 \\
& Adaptation & 61 & 4.16 & .5237 \\
& Exploring & 72 & 4.31 & .5086 \\
& Advancing & 46 & 4.27 & .5090 \\
\hline
\end{tabular}

Table 15.

ANOVA results of teachers' use of technology levels according to the T-TAS and TPACK scores

\begin{tabular}{|c|c|c|c|c|c|c|}
\hline Scales & & $\begin{array}{c}\text { Sum of } \\
\text { Squares }\end{array}$ & df & Mean Square & $\mathrm{F}$ & $\mathrm{p}^{*}$ \\
\hline \multirow{3}{*}{ T-TAS } & Between Groups & 0.524 & 1 & 0.524 & \multirow{3}{*}{2.290} & \multirow{3}{*}{.132} \\
\hline & Within Groups & 50.550 & 221 & 0.229 & & \\
\hline & Total & 51.074 & 222 & & & \\
\hline \multirow{3}{*}{ TPACK } & Between Groups & 0.818 & 1 & 0.818 & \multirow{3}{*}{2.938} & \multirow{3}{*}{.088} \\
\hline & Within Groups & 61.524 & 221 & 0.278 & & \\
\hline & Total & 62.342 & 222 & & & \\
\hline
\end{tabular}

$(* \mathrm{p}<.05)$

According to Table 14, the technology acceptance score means of the teachers who are at the levels of Exploring $(\bar{X}=4.02)$ and advancing of use $(\bar{X}=3.90))$ are higher compared to the other levels. Similarly, it is seen that the technological pedagogical content knowledge levels of the teachers who are at the levels of Exploring $(\bar{X}=4.31)$ and advancing of use $(\bar{X}=4.27)$ are higher compared to the other levels. According to Table 15, the technology acceptance and technological pedagogical content knowledge levels of mathematics teachers do not show a significant difference compared to the use of technology levels $[\mathrm{F}(1,221)$ $\left.=2.290, \mathrm{~F}_{(1,221)}=2.938, \mathrm{p}>.05\right]$.

In order to determine the relationship between the technology acceptance levels of mathematics teachers and the TPACK competency levels, the Pearson's correlation coefficient between the T-TAS and TPACK scales was considered. The results obtained by correlation analysis are shown in Table 16.

Table 16.

The relationship between the technology acceptance levels and TPACK competencies of teachers

\begin{tabular}{ccc}
\hline Scales & 1 & 2 \\
\hline 1. T-TAS & - & $.538^{*}$ \\
2. TPACK & $.538^{*}$ & - \\
\hline
\end{tabular}

*: Correlation significant at the level of .01 (two-way)

According to Table 16, there is a moderate positive and significant relationship between the technology acceptance levels and the technological pedagogical content knowledge competencies of mathematics teachers. Looking at the determination coefficient (square of the correlation coefficient) $(\mathrm{r} 2=.289)$, it is clear that $29 \%$ of the total variance in TPACK qualifications is due to the technology acceptance level. It is possible to interpret it oppositely (Büyüköztürk, 2015). 


\section{Conclusion and Suggestions}

In this study, the technology acceptance and TPACK competency levels of mathematics teachers in the distance education process that has been part of our lives with the pandemic were determined and compared according to different variables, and the relationship between them was examined.

According to the results obtained from the study, when the T-TAS scores of mathematics teachers were examined, it was determined that the technology acceptance levels were high, and when the TPACK competency scores were examined, the TPACK competency levels were determined to be high. This finding is similar to the studies conducted by Aktürk and Delen (2020) and Mutluoğlu and Erdoğan (2016). In the study conducted by Aktürk and Delen (2020), it was concluded that teachers' technology acceptance levels were high, and in the study conducted by Mutluoğlu and Erdoğan (2016), it was concluded that primary mathematics teachers' TPACK competency levels were high. According to this result, it can be said that mathematics teachers consider themselves sufficient in terms of technology acceptance and TPACK competency levels.

According to the findings obtained, it was concluded that the gender factor was effective in the technology acceptance and TPACK competencies of mathematics teachers, and that the technology acceptance and TPACK competency of male teachers was higher than that of female teachers. This result is similar to the study conducted by Baran and Ata (2013), Sarikaya (2019), Bilici and Guner (2016). In their study, Baran and Ata (2013) examined university students' use of web 2.0 technologies and concluded that male students' status of use of technology was significantly higher than female students.

In the study, it was concluded that having received in-service education on ICT did not affect the technology acceptance and TPACK competency levels of mathematics teachers. A similar result was obtained in a study conducted by Karaoğlan Y1lmaz and Binay Eyuboğlu (2018). According to this result, it can be said that since our age and the distance education process we are in, requires mathematics teachers to follow the developments in how they can use technology in their fields, it can be said that taking in-service training will not cause a difference that will affect the technology acceptance and TPACK competency levels.

From the results obtained from the examination of the technology acceptance and TPACK competency levels of mathematics teachers according to the use of graphic tablets, it was found that technology acceptance and TPACK competency levels did not make a significant difference with the use of graphic tablets. In the study conducted by Aktürk and Delen (2020), contrary to this result, it was found that the technology acceptance of teachers who use smart boards differ significantly compared to those who do not use them. According to this result, it can be noted that mathematics teachers' adoption of technology and the high benefit they see in the use of in-class applications by combining technology knowledge with field knowledge indicates the teacher's intention to use technological tools in their classes.

From the results obtained from the examination of the technology acceptance and TPACK competency levels of mathematics teachers according to age and professional seniority, it was determined that the technology acceptance and TPACK competency levels of mathematics teachers did not differ significantly according to age. In this case, it can be interpreted that individuals cannot stay away from technology with the involvement of technology into every aspect of our lives, investments made in schools and equipping classrooms with technological tools and internet infrastructure, age and professional seniority factor do not cause a significant difference between teachers' technology acceptance and TPACK levels. It shows similarity with the results obtained in the studies carried out by Sarıaya (2019), Burmabi1yık (2014) and Sabo and Archambault (2012) that the technology acceptance levels of teachers and teacher candidates do not differ significantly according to age. However, there are also studies in the literature in which the age and professional seniority factors differ according to the teacher's professional experience (Bal and Karademir, 2013; Karakaya, 2013; Bilici and Güler, 2016; Mutluoglu and Erdoğan, 2016). 
It was determined that the technology acceptance levels of mathematics teachers did not differ significantly according to the department graduated. However, it was also determined that the TPACK competencies of teachers who graduated from the mathematics department were higher than those who graduated from the mathematics teaching department. It can be interpreted that the fact that technology has become an essential part of the education process today and the content knowledge of mathematics teachers who graduated from the mathematics department may be different from those who graduated from the mathematics teaching department may be the cause of this result. This result contradicts the studies carried out by Bilici and Güler (2016), Karatas (2014) and Burmabiyık (2014). According to the opinions of the teachers obtained in the study of Bilici and Güler (2016), it was suggested that the TPACK competencies of the teachers who graduated from the mathematics department, and those who went through similar processes by receiving pedagogical formation and in-service training, may be similar.

In the study, it was determined from the data obtained by examining the relationship between technology acceptance and TPACK competency levels of mathematics teachers, that there was a positive, moderate and significant relationship between technology acceptance and TPACK competencies, and that $29 \%$ of TPACK competencies resulted from technology acceptance. According to this result, it can be noted that the TPACK competency levels of mathematics teachers with high technology acceptance levels are also high. In the study conducted by Joo, Park and Lim (2018), however, it was determined that TPACK competencies do not directly affect their intention to use the technology.

In this study, the TPACK scale was used to determine the technology acceptance levels of mathematics teachers in the distance education process, and the level of technological pedagogical content knowledge to determine the TPACK scale was used. In future studies, apart from these measurement tools used, the study can be diversified using different measurement tools. Also, by using qualitative methods, the study can be enriched and teachers' technology acceptance and TPACK levels can be understood in detail. It is possible to perform the research with teachers who continue distance education in different branches.

All teachers and students are trying to get used to a new system in distance education, which has been put into use with the spread of the Covid-19 pandemic. Keeping teachers' motivation levels at high levels during this adaptation process is considered important for the efficiency of the educational process. In addition, the content that teachers will use in their courses should also be suitable for distance learning applications. Therefore, additional studies can be carried out examining the course planning process and motivation levels of teachers in distance education.

\section{References}

Açıkgül, K. and Aslaner, R. (2015). Investigation of TPACK Confidence Perception of Prospective Elementary Mathematics Teachers. Erzincan University Journal of Education Faculty (EUJEF), 17(1). doi:10.17556/jef.04990

Aktürk, A. O. and Delen, A. (2020). The Relationship Between Teachers' Technology Acceptance Levels and Self-Efficacy Beliefs. The Science, Education, Art and Technology Journal (SEAT Journal), $4(2), 67-80$.

Akyürek, M. İ. (2020). Distance Education: A Literature Review. Medeniyet Educational Research Journal, 4(1), 1-9.

Alea, L. A., Fabrea, M. F., Roldan, R. D. A. and Farooqi, A. Z. (2020). Teachers' Covid-19 Awareness, Distance Learning Education Experiences and Perceptions Towards Institutional Readiness and Challenges. International Journal of Learning, Teaching and Educational Research, 19(6), 127144.

Aydos, M. (2015). The Impact of Teaching Mathematics With Geogebra on The Conceptual Understanding of Limits and Continuity: The Case of Turkish Gifted and Talented Students. Unpublished Master Thesis, Bilkent University, Ankara. 
Bağrıçık Yılmaz, A. and Karataş, S. (2020). Açık ve Uzaktan Öğrenmenin Temel Kavramları, Kuramları ve Felsefesi. In S. Karataş and E. Kılıç Çakmak (Eds.), Açık ve Uzaktan Öğrenme (pp. 2-29). Ankara: Pegem Akademi.

Bakioğlu, B. and Çevik, M. (2020). COVID-19 Science Teachers' Views on Distance Education in the COVID-19 Pandemic Process. Electronic Turkish Studies, 15(4).

Bal, M. S. and Karademir, N. (2013). Determining Social Science Teachers' Self-Assessment Levels With Regard to Their Technological Pedagogical Content Knowledge (TPCK). Pamukkale University Journal of Education, 34(2), 15-32, 15-32. doi:10.9779/puje468

Baran, B. and Ata, F. (2013). University Students' Web 2.0 Technologies Usage, Skill Levels and Educational Usage. Education and Science, 38(169).

Başaran, M., Doğan, E., Karaoğlu, E. and Şahin, E. (2020). A Study on Effectiveness of Distance Education, as a Return of Coronavirus (Covid-19) Pandemic Process. Academia Journal of Educational Research, 5(2), 179-209.

Bayburtlu, Y. S. (2020). Turkish Education During Covid-19 Pandemic Distance Education Process, Electronic Turkish Studies, 15(4).

Baz, F. Ç. (2016). Designing of Adaptable Web Based Online Learning Context in Confirmity with the Collated Teaching Model and Its Effect on Student's Success. Unpublished PhD Thesis, Mustafa Kemal University, Hatay.

Bilici, S. and Güler, Ç. (2016). Investigation of Teachers' TPACK Levels with Respect to Use of Instructional Technologies. Elementary Education Online, 15(3). doi:10.17051/io.2016.05210

Burmabıyık, Ö. (2014). Investigation of Perceptions of Self-Sufficiency Towards Teachers' Technological Pedagogical Content Knowledge in Terms of Different Variables (Case of Yalova). Unpublished Master Thesis, Sakarya University, Sakarya.

Büyüköztürk, Ş. (2015). Sosyal Bilimler İçin Veri Analizi El Kitabı. Ankara: Pegem Akademi.

Büyüköztürk, Ş., Akgün, Ö. E., Demirel, F., Karadeniz, Ş., and Çakmak, E. K. (2016). Bilimsel araştırma yöntemleri. Ankara: Pegem Akademi.

Davis, F. D. (1986). A Technology Acceptance Model for Empirically Testing New End-User Information Systems: Theory and Result, (Doctoral dissertation). Sloan School of Management: Massachusetts Institute of Technology.

Demir, F. and Özdaş, F. (2020). Examining Teachers' Opinions Related to Distance Education in The Covid-19 Process. Milli Eğitim Dergisi, 49(1), 273-292. doi:10.37669/milliegitim.775620

Dikkartın Övez, F. T. and Akyüz, G. (2013). Modelling Technological Pedagogical Content Knowledge Constructs of Preservice Elementary Mathematics Teachers. Education and Science, 38(170).

Durak, G. and Çankaya, S. (2020). Distance Mathematics Education Through the Eyes of Academics. In H. Gür (Ed.), Matematik ve Fen Bilimleri Eğitiminde Akademik Çalımalar (pp. 437-463). Lyon: Livre de Lyon.

Hebebci, M. T., Bertiz, Y. and Alan, S. (2020). Investigation of Views of Students and Teachers on Distance Education Practices During the Coronavirus (COVID-19) Pandemic. International Journal of Technology in Education and Science (IJTES), 4(4), 267-282.

Herand, D. and Hatipoğlu, Z. A. (2014). E-learning and Comparison of Commonly Used E-learning Platforms. Çukurova University Faculty of Economics and Administrative Sciences, 18(1).

İşman, A. (2011). Uzaktan ĕ̌itim. Ankara: Pegem Akademi.

İzmirli, S. and Akyüz, H. İ. (2017). Examining Synchronous Virtual Classroom Software. Journal of Theory and Practice in Education, 13(4), 788-810.

Karabulut, B. (2015). In The Era of Information Society Digital Natives, Immigrants and Hybrids. Pamukkale University Journal of Social Sciences Institute, 21, 11-23.

Karakuş, N., Ucuzsatar, N., Karacaoğlu, M. Ö., Esendemir, N. and Bayraktar, D. (2020). Turkish Teacher Candidates' Views on Distance Education. RumeliDE Journal of Language and Literature Studies, (19), 220-241. DOI: 10.29000/rumelide.752297. 
Karaoğlan Yılmaz, F. G. and Binay Eyüboğlu, F. A. (2018). Investigation of the Relationships Between Lifelong Learning Attitudes, Digital Native Status and Technology Acceptance of Teachers in Terms of Each Other and Various Variables. International Journal of Education Science and Technology, 4(1), 1-17.

Karasar, N. (2015). Bilimsel Araştırma Yöntemleri. Ankara: Nobel Akademi.

Karatepe, F., Küçükgençay, N. and Peker, B. (2020). What are the Perspectives of Teacher Candidates on Synchronous Distance Education? A Survey Study. Journal Of Social And Humanities Sciences Research, 7(53), 1262-1274.

King, F. B., Young, M. F., Drivere-Richmond, K. and Schrader, P. G. (2001). Defining Distance Learning and Distance Education. AACE Journal, 9(1), 1-14.

Kocayiğit, A. and Uşun, S. (2020). Attitudes of Teachers Working in Schools Affiliated to Ministry of National Education Towards Distance Education (Example of Burdur Province). International Journal of Euroasian Research, 8(23), 285-299. doi:10.33692/avrasyad.662503

Kurnaz, A., Kaynar, H., Barışık, C. Ş. and Doğrukök, B. (2020). Teachers' Views On Distance Learning. Milli Ĕgitim Dergisi, 49(1), 293-322.

Marpa, E. P. (2020). Technology in the teaching of mathematics: An Analysis of Teachers' Attitudes During the COVID-19 Pandemic. International Journal on Studies in Education, 3(2), 92-102.

Mazman, S. G. and Usluel, Y. K. (2011). ICT Integration Into Learning-Teaching Process: Models and Indicators. Educational Technology Theory And Practice, 1(1), 62-79.

Ministry of Naational Education (MNE). (2020). Digital Literacy Teacher's Guide. Retrieved from http://covid19.meb.gov.tr/covid19.html?cat=uzaktan-egitim

Mutluoğlu, A. and Erdoğan, A. (2016). Examining Primary Mathematics Teachers' Technological Pedagogical Content Knowledge (TPACK) Levels According to Their Preferred Teaching Styles. OPUS International Journal of Society Researches, 6(10).

Niess ML, Ronau RN, Shafer KG, Driskell SO, Harper SR, Johnston C, Browning C, Özgün-Koca SA, Kersaint G (2009) Mathematics teacher TPACK standards and development model. Contemp Issues Technol Teacher Educ 9(1):4-24

Odabaş, H. (2003). Internet Based Distance Education and Departments of Information and Records Management. Turkish Librarianship, 17(1), 22-36.

Öz, M. (2015). The Effects of Using a Dynamic Mathematics Software Geogebra 5.0 in Teaching the Subject of "Geometrical Object" in Seventh Grade Math Class in A Primary School on Students' Achievement. Unpublished Master Thesis, Gazi University, Ankara.

Perienen, A. (2020). Frameworks for ICT Integration in Mathematics Education-A Teacher's Perspective. EURASIA Journal of Mathematics, Science and Technology Education, 16(6).

Rogers, E. M. (1995). Diffusion of Innovations (4th ed.). Free Press, New York

Sabo, K. and Archambault, L. (2012). Tessellations in TPACK: Comparing Technological Pedagogical Content Knowledge Levels Among K-12 Online and Traditional Teachers. Paper presented at the Society for Information Technology and Teacher Education International Conference.

Sirakaya, M. (2019). Technology Acceptance of Primary and Secondary School Teachers. Inonu University Journal of the Faculty of Education, 578-590. doi:10.17679/inuefd.495886

Joo, Y. J., Park, S. and Lim, E. (2018). Factors Influencing Preservice Teachers' Intention to Use Technology: TPACK, Teacher Self-efficacy, and Technology Acceptance Model. Educational Technology and Society, 21(3), 48-59.

Tabachnick, B. G. and Fidell, L. S. (2013). Using Multivariate Statistics Boston: Pearson.

Taylor, J. C. (2001). Fifth Generation Distance Education. Instructional Science and Technology, 4(1), 114.

Ursavaş, Ö. F. (2014). Modeling and Examinig Teachers' ICT Acceptance. Unpublished PhD Thesis, Gazi University, Ankara. 
Ursavaş, Ö. F., Şahin, S. and McIlroy, D. (2014). Technology Acceptance Measure for Teachers: T-TAM. Journal of Theory and Practice in Education, 10(4), 885-917.

Yıldırım, A. and Şimşek, H. (2008). Sosyal Bilimlerde Nitel Araştırma Yöntemleri, 7. baskı., Ankara: Seçkin Yayıncılık.

Yorganc1, S. (2014). The Effects Of Web Based Distance Education Method on Students' Mathematics Achievements. Kastamonu Education Journal, 23(3), 1401-1420.

Zaranis, N. (2016). The use of ICT in Kindergarten for Teaching Addition Based on Realistic Mathematics Education. Education and Information Technologies, 21(3), 589-606. 